\title{
The dark side of dendritic cells: development and exploitation of tolerogenic activity that favor tumor outgrowth and immune escape
}

\section{Barbara Seliger * and Chiara Massa}

Institute for Medical Immunology, Martin Luther University Halle-Wittenberg, Halle (Saale), Germany

\section{Edited by:}

Kristian Michael Hargadon,

Hampden-Sydney College, USA

Reviewed by:

Mansour Mohamadzadeh, University of Florida, USA

Luis De La Cruz-Merino, Hospital

Universitario Virgen Macarena, Spain

*Correspondence:

Barbara Seliger, Institute of Medical Immunology, Martin Luther University

Halle-Wittenberg, Magdeburger

Street 2, Halle (Saale) 06112,

Germany

e-mail: barbara.seliger@uk-halle.de
Dendritic cells (DC) play a central role in the regulation of the immune responses by providing the information needed to decide between tolerance, ignorance, or active responses. For this reason different therapies aim at manipulating DC to obtain the desired response, such as enhanced cell-mediated toxicity against tumor and infected cells or the induction of tolerance in autoimmunity and transplantation. In the last decade studies performed in these settings have started to identify (some) molecules/factors involved in the acquisition of a tolerogenic DC phenotype as well as the underlying mechanisms of their regulatory function on different immune cell populations.

Keywords: dendritic cell, tumor, immune escape, tolerance, immunotherapy

\section{INTRODUCTION}

The immune system evolved with the difficult task of preserving the integrity of the "self," while protecting it from "non-self" and/or dangerous invaders, thus finding the right balance between aggression and tolerance. A central role in orchestrating the different immune cell subpopulations is played by dendritic cells (DC), the major professional antigen presenting cells (APC). Over the last two decades, many different DC subsets have been identified and classified into myeloid DC, which comprise all monocytederived cells and blood-resident $\mathrm{CD} 1 \mathrm{c}^{+} \mathrm{DC}$ and into plasmacytoid DC (PDC).

A particularly difficult task for the immune system is to fight tumors, since they derive from the "self," but based on their high proliferative potential they are dangerous for the survival of the host. Moreover, due to the high mutation rates of tumor cells the selection pressure posed by an immune response can result in tumor immunoediting with the outgrowth of immune escape variants or the induction of a suppressive microenvironment. In line with the central role of DC in balancing response versus tolerance, many of the immune escape mechanisms displayed by cancer cells affect DC. These include alterations in the frequency and/or function of circulating and tumor-infiltrating DC in patients with tumors of different histologies. In particular, DC in cancer patients can be affected in their differentiation capacity, with either enhanced apoptosis or skewed phenotype toward immature cells with suppressive properties collectively named myeloid derived suppressor cells [MDSC; $(1,2)$ ], in their ability to process and/or present tumor-associated antigens (TAA) and in their ability to interact with effector cells, e.g., to activate and/or correctly polarize them.

Studies performed with DC differentiated in vitro in the presence of tumor cells or of their conditioned medium as well as with purified tumor-infiltrating DC identified the underlying mechanisms responsible for such alterations leading to a pro-tumorigenic phenotype. This review summarizes the known processes employed by tumor cells to subvert professional APC (summarized in Table 1) and how the increasing knowledge can not only help in fighting cancer, but also in inducing tolerance to transplanted organs and suppression of autoimmune diseases.

\section{MYELOID DC AND CANCER}

Tumor cells can influence the phenotype and function of myeloid cells at different time points of their life and with distinct mechanisms. These include the metabolic shift of tumor cells toward the anaerobic glycolytic pathway for glucose degradation resulting in increased concentrations of extracellular lactate and an acidification of the microenvironment, the so-called Warburg effect (3). Monocytes cultured in vitro in the presence of lactate and low $\mathrm{pH}$ have shown an impaired differentiation toward DC favoring either an expansion of MDSC (4) or of macrophages that promote a Th17 polarization (5). Despite prolonged incubation in the presence of lactate impairs DC responsiveness to lipopolysaccharide [LPS; (6)], a transient exposition promotes DC maturation and enhances their ability to induce a type 1 immune response (7). In addition to $\mathrm{pH}$ alterations, the tumor microenvironment is characterized by hypoxia that skews DC toward a type 2 polarization (8), reduces their ability to uptake antigens $(\mathrm{Ag})$, and alters their migratory properties (9).

In addition, expression of hyaluronan (HA), a component of the extracellular matrix of the tumor stroma, correlates with tumor invasiveness and poor survival of patients with ovarian, breast, and colorectal cancer (10-13), while high HA levels correlate with more differentiated tumor phenotype and an enhanced survival in patients with oral squamous carcinoma (14). The effects of HA 
Table 1 | Effects of tumor-derived molecules on APC functions.

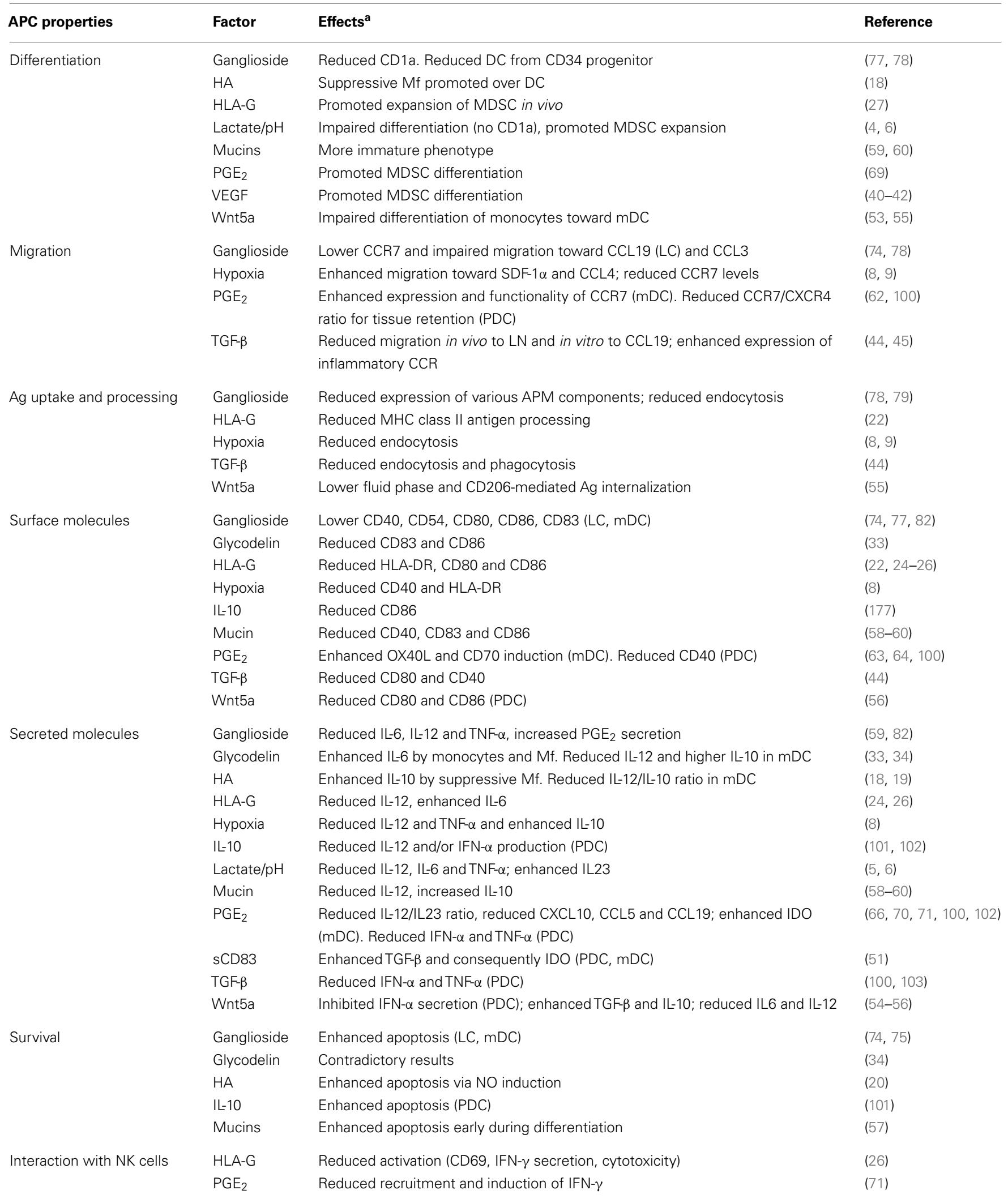


Table 1 | Continued

\begin{tabular}{|c|c|c|c|}
\hline APC properties & Factor & Effects $^{a}$ & Reference \\
\hline Interaction with nk-T cells & TGF- $\beta$ & Reduced CD1d and lipid presentation & $(46)$ \\
\hline \multirow[t]{12}{*}{ Interaction with T cells } & Ganglioside & Reduced allo-MLR (LC). Reduced proliferation to TT and allo-MLR (mDC) & $(74,78,81,82)$ \\
\hline & Glycodelin & Reduced induction of proliferation. Reduced IFN- $\gamma$ secretion & $(28,34)$ \\
\hline & $\mathrm{HA}$ & Enhanced T cell apoptosis via ROS production & (19) \\
\hline & HLA-G & Reduced allo-MLR, more IL-10 secreting CD8+ T, anergic CD4+ T & $(22,25)$ \\
\hline & Hypoxia & Enhanced IL-4 over IFN- $\gamma$ secretion, type 2 skew & (8) \\
\hline & IL-10 & $\begin{array}{l}\text { Enhanced proliferation of CD4+ } \mathrm{T} \text { and skew toward Th2 (PDC). Reduced } \\
\text { allo-MLR and anergy induction }\end{array}$ & $(102,177)$ \\
\hline & Lactate/pH & Reduced Ag specific CD8 ${ }^{+}$T proliferation; enhanced IL-17 over IFN- $\gamma$ secretion & $(5,6)$ \\
\hline & Mucin & Reduced allo-MLR, reduced IFN- $\gamma$ secretion by $\mathrm{CD}^{+} \mathrm{T}$ & $(60)$ \\
\hline & $\mathrm{PGE}_{2}$ & $\begin{array}{l}\text { Enhanced IL-17 and reduced IFN- } \gamma \text {, inhibition via IDO and soluble CD25 (mDC). } \\
\text { Enhanced proliferation of CD4+ T and skew toward Th2 (PDC) }\end{array}$ & $(65,66,70,102)$ \\
\hline & sCD83 & Induction/expansion of CD4 ${ }^{+} \mathrm{CD}_{2} 5^{+} \mathrm{Foxp}^{+}$Treg & $(51)$ \\
\hline & TGF- $\beta$ & Reduced proliferation in allo-MLR and to peptide, reduced IFN- $\gamma$ secretion & $(44)$ \\
\hline & Wnt5a & Reduced IFN- $\gamma$ secretion, higher IL-10 secretion. Reduced proliferation & $(54,55)$ \\
\hline
\end{tabular}

a When nothing given between brackets, $M D C$ are considered.

PDC, plasmacytoid DC; LC, Langerhans cells; Mf, macrophages; mDC, myeloid DC; LN, lymph node; MLR, mixed leukocyte reaction.

on DC are controversial and possibly related to its size: whereas low molecular weight HA can induce DC maturation in vitro (15, 16) and improve their functionality in vivo as cancer vaccine (17), intermediate sized HA impairs monocyte differentiation resulting in immunosuppressive APC characterized by a macrophage-like phenotype $\left(\mathrm{CD} 14^{+}, \mathrm{CD} 1 \mathrm{a}^{\text {low }}\right)$, a reduced upregulation of costimulatory molecules and inflammatory cytokines after stimulation with toll-like receptor (TLR) ligands and an enhanced secretion of interleukin (IL)-10 (18, 19). Moreover, HA-conditioned DC can secrete nitric oxide (NO) and reactive oxygen species (ROS) that can induce apoptosis in DC and in co-cultured T cells, respectively $(19,20)$.

An other escape strategy exploited by tumor cells is the hijacking of endogenous mechanisms of tolerance induction used by immuno-privileged organs. This is mediated by the non-classical HLA-G antigen, which exhibit a tightly controlled physiologic expression restricted to cornea, thymic epithelial cells, reproductive organs, embryonal tissues, and the extravillous cytotrophoblasts at the maternal-fetal interface. Furthermore, HLA-G is often expressed in solid and hematologic tumors either as a transmembrane and/or a secreted/shed protein, thereby protecting tumor cells from the cytolytic activity of natural killer (NK) and T cells (21). In addition, HLA-G can also impair myeloid DC by binding to the inhibitory receptors ILT2 and ILT4 in humans and PIR-B in mice (22-24). Receptor triggering by HLA-G inhibits the nuclear translocation of the transcription factor NF-кB (25), which is consequently accompanied by reduced expression of costimulatory molecules and proinflammatory cytokines as well as impaired presentation of MHC class II-restricted epitopes (22). As a consequence, HLA-G treated DC lack the ability to induce NK cells activation (26) and promote anergy of effector cells and differentiation of regulatory T cell [Treg; (22)]. Furthermore, tumor-expressed HLA-G induced suppressive MDSC and tumor growth in vivo (27).
Glycodelin (previously called placental protein 14 or PP14, $\alpha 2-$ globulin, progesterone-associated endometrial protein or zonabinding inhibitory factor) has been originally identified as the molecule responsible for the immunosuppressive activity in the decidua during early gestation (28), but is also expressed in tumors of the reproductive tract, e.g., ovarian carcinoma, where its glycosylated form glycodelin A (GdA) correlated with unfavorable prognosis (29). Furthermore, glycodelin correlate with a worse patients' prognosis in familiar, non-BRCA1/2 breast carcinoma (30) and in lung cancer (31). In vitro characterization of glycodelin function demonstrated suppressive effects on all immune cell populations (32), including DC. Treatment of DC with GdA results in lower expression levels of costimulatory molecules, a low IL-12/IL-10 ratio (33), and a reduced ability to induce a type 1 polarization of effector cells (34). Depending on the culture conditions, GdA has also been reported to induce or suppress apoptosis in monocytes [see discussion in Ref. (34)].

Other "physiologic" tolerogenic factors borrowed by tumor cells include indoleamine 2,3-dioxygenase [IDO; (35)], adenosine production via CD73 expression (36), and secretion of IL-10 (37, $38)$, transforming growth factor- $\beta$ [TGF- $\beta$; (39)] or soluble CD83 (sCD83).

Transforming growth factor- $\beta$ plays not only a role in MDSC development, like vascular endothelial growth factor [VEGF; (4042)], IL-6 and/or macrophage colony stimulating factor [M-CSF; (43)], but also impairs the DC migratory capacity by altering the expression pattern of chemokine receptors $(44,45)$ and inducing downregulation of CD1d thus impairing DC interactions with NK-T cells (46).

sCD83 was found in total blood cell cultures after stimulation and might represent a feed back mechanism to shut down an immune response (47). Indeed, enhanced serum levels of sCD83 detected in hematologic malignancies and solid tumors, like lung carcinoma correlate with shorter tumor-free survival (48-50). 
In vitro treatment of $\mathrm{DC}$ with recombinant $\mathrm{sCD} 83$ results in enhanced IDO production and induction of TGF- $\beta$ producing Foxp3 ${ }^{+}$Treg (51).

An additional strategy of immune escape mechanisms exploited by tumor cells consists in the upregulation of molecules with negative effects on DC. These include alterations in the $\mathrm{Wnt} / \beta$-catenin pathway inducing activation of MerTK receptor (c-mer proto-oncogene tyrosine kinase) in infiltrating cells like macrophages and DC that help tumor growth in vivo (52). In vitro studies have found that tumor-derived Wnt5a can impair the differentiation of monocytes toward DC (53) and inhibit the maturation response to TLR ligand by myeloid DC $(54,55)$ as well as by PDC (56).

Mucins are expressed by many epithelial tumors and their presence during differentiation of monocytes toward DC results in less differentiated cells with increased apoptosis (57), impaired response to TLR ligand stimulation, cytokine production skewed toward the immunosuppressive IL-10, impaired ability to induce proliferation of $\mathrm{T}$ cells, and enhanced induction of suppressive $\mathrm{T}$ cells (58-60). Those effects seem to be mediated by binding to the mannose receptor, siglec-3 and -9 (57-59).

A hallmark of many tumors is the secretion of high levels of prostaglandin $\mathrm{E}_{2}\left(\mathrm{PGE}_{2}\right)$ due to upregulation of cyclooxygenase (COX)1/2. The consequences of $\mathrm{PGE}_{2}$ on DC functionality are complex. While it represent a component of the "gold standard" cocktail for vaccine DC maturation (61) due to its role in promoting CCR7-mediated migration (62), and it also induces the expression of costimulatory molecules like OX40-L and CD70 promoting $\mathrm{T}$ cell functions $(63,64)$, it can inhibit the synthesis of IL-12p70 (65), while favoring the secretion of IL-23 that promote Th17 immune responses (66) and tumor development (67, 68). Moreover, $\mathrm{PGE}_{2}$ enhances MDSC differentiation (69), induces expression of IDO and soluble CD25 that inhibit T cell stimulation (70) and impairs the cross talk with NK cells (71). A possible explanation for the contrasting effects can be due to the specific receptor triggered by $\mathrm{PGE}_{2}(72)$ and/or the relative ratio between $\mathrm{PGE}_{2}$-treated DC and effector cells (73).

Altered and/or secreted gangliosides have also been demonstrated to affect DC differentiation and survival (74-78). Moreover, gangliosides impair the ability of monocytes to induce $\mathrm{T}$ cell proliferation due to a downregulated expression of components of the antigen processing machinery $[\operatorname{APM} ;(79,80)]$, a suppressed costimulation and a reduced cytokine production $(81,82)$. In vivo, a correlation between elevated levels of the ganglioside GM3 and a higher frequency of immature DC was found in non-small-cell lung cancer (83).

Furthermore, "tumor-deviated" DC/MDSC exhibit an altered phosphorylation pattern of STAT3 $(84,85)$ that has also been linked to the inhibition of IL-12p40 transcription (86) and/or of p38 (87) that is involved in the induction of Th17 responses (88).

In addition to boost the immune suppression, tumorconditioned DC can also provide direct help to tumor cells by secreting mitogens for the tumor cells (89), by favoring the epithelial mesenchymal transition (90), by promoting their invasiveness and ability to metastasize $(8,90)$ and by inducing angiogenesis $(91,92)$.

\section{PDC AND CANCER}

Plasmacytoid DC have been found in the infiltrate of various human solid tumors like melanoma, breast, ovarian, and head and neck carcinoma, where they frequently correlated with a worse patients' prognosis (93-96). Functionally, PDC can be recruited by the tumor through its secretion of CXCL12 (also called SDF$1 \alpha$ ) and CCL20 (97-99). Then, factors locally released by tumor cells, like TGF- $\beta$, tumor necrosis factor (TNF)- $\alpha$, IL-10, and PEG 2 $(95,100-104)$ as well as triggering of the PDC-specific receptor ILT7 $(105,106)$ induce the immunosuppressive properties of PDC. Indeed, tumor-conditioned PDC display a semi-mature phenotype with expression of costimulatory molecules but impaired secretion of IFN- $\alpha(93,101,103)$. In addition, tumor-associated, tolerogenic PDC showed an upregulation of the transcription factor Foxo3 (107) and an impaired migration to lymphoid organs due to reduced CCR7 expression (100).

Characterization of the immunosuppressive activity of PDC in vitro have highlighted their ability to induce unresponsiveness of effector cells, to promote the development of suppressive CD8 ${ }^{+}$ $\mathrm{T}$ cells, to differentiate naïve $\mathrm{CD} 4^{+} \mathrm{T}$ cells toward Foxp $3^{+}$or IL-10 producing Treg as well as to expand pre-existing Treg (108-113). From the molecular point of view, important roles have been identified for ICOS ligand (ICOS-L), IDO, notch ligand delta-like 4 (Dll4), and granzyme B. ICOS-L is upregulated shortly after maturation induced by CD40-L or TLR9 triggering (108), is involved in inducing IL-10 production in CD45RO ${ }^{+} \mathrm{T}$ cells (114) and in sustaining the survival and proliferation of Foxp $3^{+}$Treg (115). A role in vivo for this pathway is supported by the co-localization between $\mathrm{ICOS}^{+}$Treg and ICOS-L $\mathrm{L}^{+}$PDC within breast and ovarian carcinoma $(115,116)$. Murine and human PDC can produce IDO in vitro upon triggering of TLR9, CTLA-4, GITR, or CD200 (117-119). PDC expressing IDO have been identified in melanoma draining lymph nodes in murine models and human patients and have been correlated with the activation of naive and mature Treg (120-122). In murine models, the constitutively expressed Dll4 allow PDC to induce Th1 cells to produce IL-10 even under type 1 polarizing conditions, thus favoring the shut down of an immune response (123). Granzyme B, whose secretion by PDC is boosted by tumor-derived IL-3 and IL-10, is involved in the downregulation of the $\mathrm{CD} 3 \zeta$ chain of $\mathrm{T}$ effector cells, thereby resulting in their anergy or deletion by apoptosis induction $(124,125)$.

In addition to their immunosuppressive role, PDC play a protumorigenic role by promoting angiogenesis via secretion of TNF$\alpha$ and IL-8 (126) and favoring metastasis dissemination into the bone (127).

\section{IMPROVED PROTOCOLS FOR DC-BASED VACCINATION AGAINST CANCER}

Two major strategies of DC-based tumor immunotherapy have been implemented. The first is based on the ex vivo production and manipulation of DC that are then injected into the patients while the second targets the DC directly in vivo (Figure 1).

The classical strategy for the first approach consists in the differentiation of $\mathrm{CD}_{14}{ }^{+}$circulating monocytes or $\mathrm{CD}^{+} 4^{+}$-mobilized precursor cells into immature DC by culturing them in the presence of granulocyte-monocyte colony stimulating factor (GMCSF) and IL-4 for 7 days, after which they are loaded with TAA 


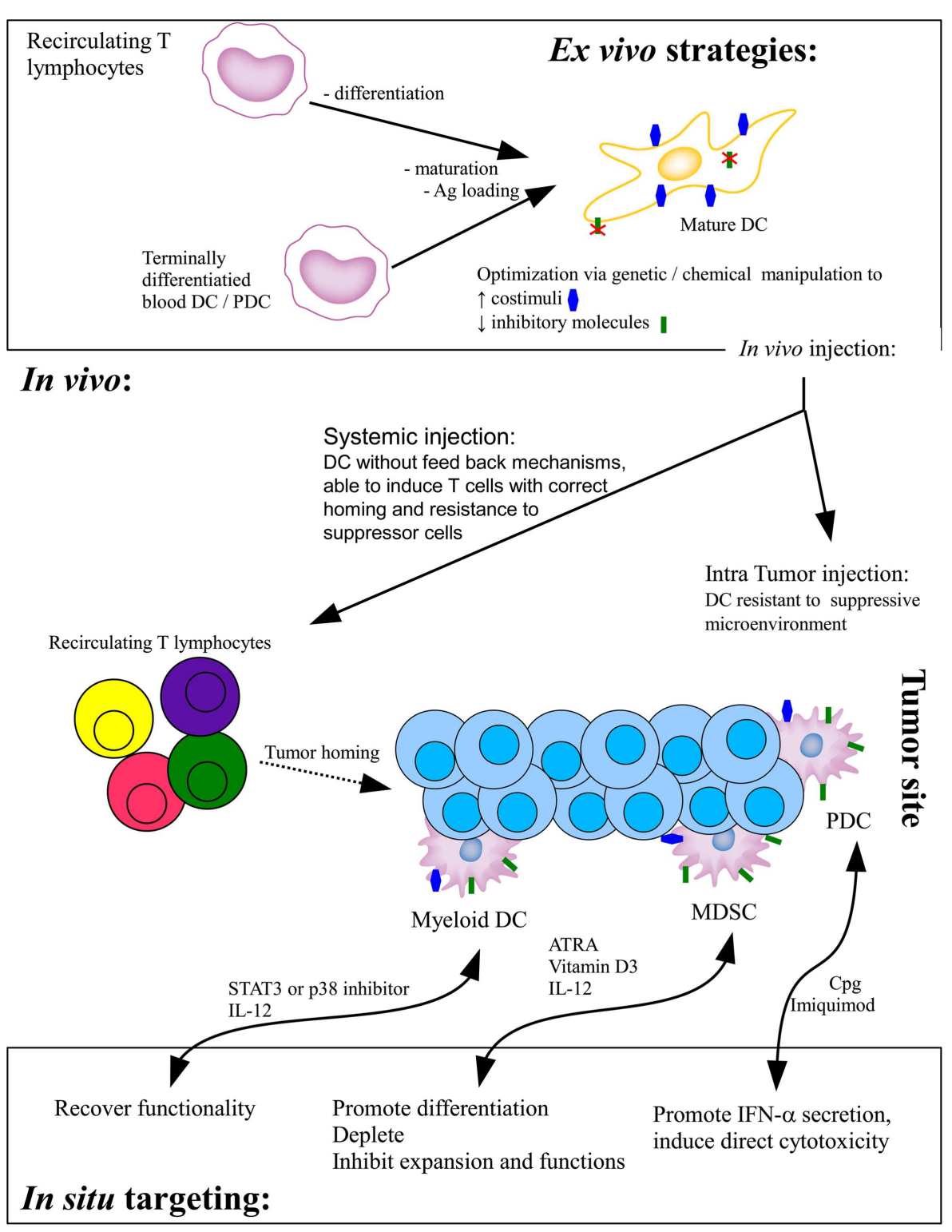

FIGURE 1 | Current DC-based strategies of tumor immunotherapy. In the ex vivo strategy, monocytes-derived immature DC or terminally differentiated blood DC are loaded with tumor antigens and/or induced to mature before in vivo injections. Whereas systemically injected DC will migrate to the draining lymph node to prime effector $T$ cells, intratumorally injected DC have to interact with effector cells within the suppressed microenvironment. Direct in situ targeting strategies aim at recovering the functionality of infiltrating DC, either promoting their correct differentiation or providing stimuli to foster their functionality. Ag, antigen; ATRA, all-trans retinoic acid. and induced to mature before in vivo injection. Studies performed using cells from patients with different solid as well as hematologic cancer histotypes have demonstrated that precursor cells are either not irreversibly impaired and can be matured with this protocol or that is possible to rescue their differentiation into functional DC upon inhibition of STAT3, p38, and/or IL-6 $(128,129)$. Despite the good results obtained in vitro with patient-derived DC, and the induction of immune response in treated patients demonstrated by expanded Ag-specific T cells and delayed type hypersensitivity (DTH) reactions, the first clinical trials with vaccine DC resulted in poor clinical outcome. Based on the increased knowledge of the
DC biology and of tumor escape mechanisms the protocol for the ex vivo production of vaccine DC has to be optimized (Box 1 ).

The initial poor results of DC-based immunotherapy could be due to the immature or only partially mature phenotype of the DC, and in particular to their reduced levels of IL-12 secretion. Thus, many alternative maturation protocols have been developed, which induce DC with an enhanced IL-12 secretion and functionality in vitro, with some of them that have also reached clinical application. The "alpha type-1 polarized DC" obtained upon maturation in the presence of IL- $1 \beta$, IFN- $\alpha$, IFN- $\gamma$, poly IC, and TNF- $\alpha$ (130) have been tested in patients with recurrent glioma 


\section{Box 1 | Optimization of DC-based tumor immunotherapy.}

Different anatomical and tumor derived factors pose problems to the success of DC-based therapy. Following is a list of key points that have to be optimized.

(A) Ex vivo DC preparation

- DC subset: terminally differentiated blood DC (PDC, CD1C ${ }^{+}$DC, mixed) or monocyte derived DC (GM-CSF + IL-4, GM-CSF + IFN- $\alpha$, GM-CSF + IL-15; standard 7 days or shortened 2-3 days protocol).

- Antigen loading: protein, DNA, or mRNA; one or multiple Ag, defined or total tumor repertoire.

- Maturation:TLR-ligand(s) (poly IC, MPLA, R848) and/or immune-derived (CD40-L, IFN- $\gamma$ ). Is PGE2 to be added for the migratory ability?

- Targeted effector cells: CD8 ${ }^{+}$T cell only; also CD4 ${ }^{+}$T helper and/or innate effector cells (NK, iNKT, $\gamma \delta T$ cells)

(B) Vaccination protocol:

- Injection route: intratumor versus systemic (intradermal, intramuscular, subcutaneous, intranodal)

- Number of injection and distance in between

- Optimal DC dose

- Combination with other treatment modalities (remove suppressive populations, reduce local immunosuppression, enhance tumor permeability...)

(131, 132), melanoma, and colorectal cancer (NCT00390338 and NCT00558051 at http://www.clinicaltrials.gov, respectively), whereas DC stimulated with LPS and IFN- $\gamma$ have been used for the treatment of patients with breast cancer $(133,134)$. DC stimulated with the streptococcus-derived immunotherapeutic agent OK432 have been used against hepatocellular carcinoma (135) and colorectal cancer (136).

In parallel to the manipulation of the maturation protocol, the type of DC was also optimized. Alternative differentiation protocols for monocytes have been tested to obtain more physiologic DC types. GM-CSF has been combined with IFN- $\alpha$ to induce inflammatory DC, which have already been tested in patients with medullary thyroid carcinoma (137), or with IL-15 to induce Langerhans-like DC that despite the enhanced functionality in vitro did not provide higher responses in melanoma patients when compared to standard DC (138). Furthermore, terminally differentiated DC have been used both as single or mixed populations. Regarding the myeloid subset, in a preclinical trial sufficient amount of $\mathrm{CD} \mathrm{c}^{+}$blood DC have been purified from healthy as well as melanoma and Bowel cancer disease patients under GMP (good manufacturing practice) conditions and could be induced to secrete proinflammatory cytokines, thus opening the way for a possible clinical application (139). Two different approaches using PDC have been developed. A leukemic cell line with PDC characteristic has been isolated and, after having demonstrated functional activity in humanized murine models (140) and with melanoma PBL in vitro (141) will be evaluated in a clinical trial in HLA-matched melanoma patients (NCT01863108). In contrast, de Vries and co-workers have employed autologous, patientderived PDC in a phase I clinical trial against melanoma (142). A GMP platform has been established to purify all subtypes of circulating APC resulting in a population able to induce Agspecific CTL both from healthy donors and myeloma patients (143). The injection of a highly purified DC population does not seem to be required since the sipuleucel-T (also called APC8015 or Provenge ${ }^{\circledR}$ ) vaccination approved by the Food and Drug Administration (FDA) for treatment of prostate cancer patients is based on a highly mixed population, in which the DC targeted with TAA only represent a small component $(144,145)$.
Other optimizations have been also evaluated in order to modulate the suppressive environment that impair the in vivo ability of the vaccine DC to prime immune responses. This is mediated by rendering DC insensitive to the tumor-induced suppressive microenvironment by blocking inhibitory signaling pathways, like TGF- $\beta(146,147)$, IL-6 (148), and STAT3 $(129,149,150)$. On the other side, the costimulatory function of DC have been further improved by providing the $\mathrm{T}$ lymphocytes with all required positive signals and/or the absence of negative feedback regulators in order to acquire full functionality and resistance to suppressor cells. DC unable to produce IL-10 (151, 152), insensitive to CTLA4 triggering (153), providing enhanced levels of CD70 (154-157), CD80 (154), or GITR-L costimulation $(153,158)$ have proved to induce $\mathrm{T}$ cells with enhanced resistance to Treg suppression, delayed induction of tolerance as well as reversion of the tolerized status. Some of those "costimulatory enhanced" DC have also started the path of clinical trials like the TriMix DC (expressing CD40L, CD70, and a constitutively active TLR4 receptor) in melanoma patients $(159,160)$.

To provide a more general pro-stimulatory phenotype, multiple signaling pathways have also been enhanced by either inducing expression of the transcription factor T-bet $(161,162)$ or by silencing A20, an inhibitor of signaling pathway downstream of TLR and TNF receptors (163) resulting in DC with improved functionality. Similarly, with the increased knowledge of the important role of micro RNA (miR) in the fine tuning of gene transcription and their role in the immune response and in DC functions (164), DC-specific miR have been targeted. For example, inhibition of miR-22 and miR-503, two miRNA upregulated in DC upon coculture with tumor cells, resulted in improved therapeutic activity due to enhanced DC survival (165).

The major aim of the second line of therapy is to revert the tolerized phenotype of tumor-infiltrating and/or recirculating DC in order to allow proper activation of effector cells. The most clinically advanced strategies are those focusing on PDC and using ligands of the TLR-7 and -9 to recover their IFN- $\alpha$ secreting capabilities. After the successful use of imiquimod and CpG-containing oligonucleotides in murine models, many clinical trials have also been performed (166), leading to the approval of imiquimod for 
cancer immunotherapy by the European Medicines Agency and the FDA. A problem with such a strategy is the fact that in some, but not all tumors a downregulation of the two TLR in tumorinfiltrating PDC have been reported (93). At the basis of the positive outcome upon PDC in situ triggering there can be not only the activation of other immune cells and the inhibition of Treg (167), but also a direct tumoricidal activity upon upregulation of TRAIL and granzyme B $(168,169)$. Is to be underlined that the upregulation of granzyme B by PDC can also have detrimental effect by killing T cells $(124,125,169)$. An other reported effect of $\mathrm{CpG}$ injection is the differentiation of MDSC toward functional monocytes with consequent reduction in the amount of suppressive cells $(170,171)$.

On the side of targeting myeloid DC in vivo, similar approaches to the ex vivo manipulation have been tested. Chemical inhibitors of negative signaling pathways like STAT3 (150), or positive modulators like miR-155 (172), have been injected in vivo with the aim to be uptaken by DC and to revert their tolerogenic phenotype and promote immune-mediated tumor rejection. Provision of missing IL-12 through different technical approaches have demonstrated that in addition to the stimulation of NK and T cells, also myeloid cells are positively affected with the activation of cytotoxic macrophages and reversion of MDSC with loss of their suppressive properties $(173,174)$. Many different strategies are also aiming at the removal of MDSC acting on their differentiation and/or suppressive functions (175). For example all-trans retinoic acid (ATRA), a compound reducing MDSC number and function has been combined to DC vaccination in a phase I trial in small cell lung cancer patients (176).

\section{EXPLOITATION OF TOLEROGENIC DC IN TRANSPLANTATION AND AUTOIMIMUNITY}

In the setting of autoimmunity and transplantation the aim of immunotherapy is to reduce inflammation and to induce a local and/or antigen-specific immunosuppression/tolerance in order to avoid organ rejection and reduce the disease score without increasing the risk of opportunistic infections. Like for tumor immunotherapy, DC have been manipulated ex vivo or directly targeted in situ.

Tolerogenic DC have been differentiated in vitro from human monocytes and murine bone marrow cells upon culture in the presence of different combination of IL-10 (177), TGF- $\beta$ (178), vitamin D3 (179), dexamethasone (180), protein kinase C inhibitor (181), and rapamycin (182). These cells are characterized by a semi-mature phenotype, the ability to expand Treg and to preserve such properties even in an inflamed microenvironment, as mimicked by stimulation with TLR ligands $(183,184)$. Murine models of organ transplantation as well as different autoimmune diseases have demonstrated the therapeutic applicability of such tolerogenic DC (185-188) and opened the way to preclinical evaluation in multiple sclerosis (189) as well as in a phase I trial in rheumatoid arthritis [RA; (190)]. Similarly, the good results obtained with non-obese diabetic (NOD) mice injected with DC silenced in the major costimulatory molecules [i.e., CD40, CD80 and CD86; (191)] have opened the way for a phase I safety study in patients with type 1 diabetes (192). In the setting of organ transplantation, "classical" murine bone marrow-derived DC from the organ donor have been either triggered with tetramer of sHLA-G1 (25) or silenced in NF-кB (193) in order to induce a transplant-specific tolerance that allow (longer) acceptance of the graft.

Direct in situ targeting of DC has also been implemented in order to promote local and/or antigen specific tolerance. Clinical trials have been performed with apilimod (or STA5326), a specific inhibitor of IL-12 and IL-23, which are the central mediators of the Th1 and Th17 responses involved in autoimmunity. Whereas in psoriasis a reduction in inflammatory cytokine and DC infiltration of the skin lesions was observed upon apilimod (194), no robust clinical improvement was found in RA (195) and contrasting results were reported in Crohn's disease $(196,197)$. Although still in the preclinical phase systemic or topic injection of sCD83 was able to prolong survival of grafted organs $(51,198)$ as well as to reduce experimental autoimmune encephalomyelitis (EAE) in both prophylactic and therapeutic setting (199). Additional strategies inducing antigen specific tolerance consist in coupling the desired antigen to antibodies or ligands for specific receptors expressed by DC. Examples are DEC-205 (200, 201), the human DC immunoreceptor (DCIR) $(202,203)$, and the murine acid binding Ig-like lectin $\mathrm{H}$ [siglec-H; (204)] that induce specific tolerance to the antigen they have been targeted with.

\section{CONCLUSION}

Despite the ever growing knowledge on the immunologic function of DC and how tumor cells try to subvert them, a long way has still to be performed before defining the best protocol of vaccination regarding not only the maturation/resistance of the DC but also the road of injection, the number of injections, the type of antigen(s) and the loading strategy (see Box 1). Of particular interest is the recent report that in therapeutic setting a single immunization performs better alone that with a following boost, a setting that is on the contrary highly favorable in prophylactic immunization (205).

\section{REFERENCES}

1. Gabrilovich DI, Nagaraj S. Myeloid-derived suppressor cells as regulators of the immune system. Nat Rev Immunol (2009) 9:162-74. doi:10.1038/nri2506

2. Nagaraj S, Gabrilovich DI. Myeloid-derived suppressor cells in human cancer. Cancer J (2010) 16:348-53. doi:10.1097/PPO.0b013e3181eb3358

3. Vander Heiden MG, Cantley LC, Thompson CB. Understanding the Warburg effect: the metabolic requirements of cell proliferation. Science (2009) 324:1029-33. doi:10.1126/science.1160809

4. Husain Z, Huang Y, Seth P, Sukhatme VP. Tumour-derived lactate modifies antitumour immune response: effect on myeloid-derived suppressor cells and NK cells. J Immunol (2013) 191:1486-95. doi:10.4049/jimmunol.1202702

5. Shime H, Yabu M, Akazawa T, Kodama K, Matsumoto M, Seya T, et al. Tumoursecreted lactic acid promotes IL-23/IL-17 proinflammatory pathway. J Immunol (2008) 180:7175-83.

6. Gottfried E, Kunz-Schughart LA, Ebner S, Mueller-Klieser W, Hoves S, Andreesen R, et al. Tumour-derived lactic acid modulates dendritic cell activation and antigen expression. Blood (2006) 107:2013-21. doi:10.1182/blood2005-05-1795

7. Martínez D, Vermeulen M, von Euw E, Sabatté J, Maggíni J, Ceballos A, et al. Extracellular acidosis triggers the maturation of human dendritic cells and the production of IL-12. J Immunol (2007) 179:1950-9.

8. Yang M, Ma C, Liu S, Sun J, Shao Q, Gao W, et al. Hypoxia skews dendritic cells to a T helper type 2-stimulating phenotype and promotes tumour cell migration by dendritic cell-derived osteopontin. Immunology (2009) 128:e237-49. doi:10.1111/j.1365-2567.2008.02954.x

9. Elia AR, Cappello P, Puppo M, Fraone T, Vanni C, Eva A, et al. Human dendritic cells differentiated in hypoxia down-modulate antigen uptake and 
change their chemokine expression profile. J Leukoc Biol (2008) 84:1472-82. doi:10.1189/jlb.0208082

10. Anttila MA, Tammi RH, Tammi MI, Syrjänen KJ, Saarikoski SV, Kosma VM. High levels of stromal hyaluronan predict poor disease outcome in epithelial ovarian cancer. Cancer Res (2000) 60:150-5.

11. Auvinen P, Tammi R, Parkkinen J, Tammi M, Agren U, Johansson R, et al. Hyaluronan in peritumoural stroma and malignant cells associates with breast cancer spreading and predicts survival. Am J Pathol (2000) 156:529-36. doi:10.1016/S0002-9440(10)64757-8

12. Ropponen K, Tammi M, Parkkinen J, Eskelinen M, Tammi R, Lipponen P, et al. Tumour cell-associated hyaluronan as an unfavorable prognostic factor in colorectal cancer. Cancer Res (1998) 58:342-7.

13. Zhang L, Underhill CB, Chen L. Hyaluronan on the surface of tumour cells is correlated with metastatic behavior. Cancer Res (1995) 55:428-33.

14. Kosunen A, Ropponen K, Kellokoski J, Pukkila M, Virtaniemi J, Valtonen $\mathrm{H}$, et al. Reduced expression of hyaluronan is a strong indicator of poor survival in oral squamous cell carcinoma. Oral Oncol (2004) 40:257-63. doi:10.1016/j.oraloncology.2003.08.004

15. Termeer CC, Hennies J, Voith U, Ahrens T, Weiss JM, Prehm P, et al. Oligosaccharides of hyaluronan are potent activators of dendritic cells. J Immunol (2000) 165:1863-70.

16. Yang R, Yan Z, Chen F, Hansson GK, Kiessling R. Hyaluronic acid and chondroitin sulphate a rapidly promote differentiation of immature dc with upregulation of costimulatory and antigen-presenting molecules, and enhancement of NF-kappaB and protein kinase activity. Scand J Immunol (2002) 55:2-13. doi:10.1046/j.0300-9475.2001.01033.x

17. Alaniz L, Rizzo M, Garcia MG, Piccioni F, Aquino JB, Malvicini M, et al. Low molecular weight hyaluronan preconditioning of tumour-pulsed dendritic cells increases their migratory ability and induces immunity against murine colorectal carcinoma. Cancer Immunol Immunother (2011) 60:1383-95. doi:10.1007/ s00262-011-1036-0

18. Kuang D, Wu Y, Chen N, Cheng J, Zhuang S, Zheng L. Tumour-derived hyaluronan induces formation of immunosuppressive macrophages through transient early activation of monocytes. Blood (2007) 110:587-95. doi:10.1182/blood2007-01-068031

19. Kuang D, Zhao Q, Xu J, Yun J, Wu C, Zheng L. Tumour-educated tolerogenic dendritic cells induce CD3 epsilon down-regulation and apoptosis of T cells through oxygen-dependent pathways. J Immunol (2008) 181:3089-98.

20. Yang T, Witham TF, Villa L, Erff M, Attanucci J, Watkins S, et al. Gliomaassociated hyaluronan induces apoptosis in dendritic cells via inducible nitric oxide synthase: implications for the use of dendritic cells for therapy of gliomas. Cancer Res (2002) 62:2583-91.

21. LeMaoult J, Rouas-Freiss N, Carosella ED. Immuno-tolerogenic functions of HLA-G: relevance in transplantation and oncology. Autoimmun Rev (2005) 4:503-9. doi:10.1016/j.autrev.2005.04.006

22. Ristich V, Liang S, Zhang W, Wu J, Horuzsko A. Tolerization of dendritic cells by HLA-G. Eur J Immunol (2005) 35:1133-42. doi:10.1002/eji.200425741

23. Liang S, Baibakov B, Horuzsko A. HLA-G inhibits the functions of murine dendritic cells via the PIR-B immune inhibitory receptor. Eur J Immunol (2002) 32:2418-26. doi:10.1002/1521-4141(200209)32:9<2418::AID-IMMU2418>3. $0 . \mathrm{CO} ; 2-\mathrm{L}$

24. Liang S, Ristich V, Arase H, Dausset J, Carosella ED, Horuzsko A. Modulation of dendritic cell differentiation by HLA-G and ILT4 requires the IL6 - STAT3 signaling pathway. Proc Natl Acad Sci U S A (2008) 105:8357-62. doi:10.1073/pnas.0803341105

25. Liang S, Horuzsko A. Mobilizing dendritic cells for tolerance by engagement of immune inhibitory receptors for HLA-G. Hum Immunol (2003) 64:1025-32. doi:10.1016/j.humimm.2003.08.348

26. Gros F, Cabillic F, Toutirais O, Maux AL, Sebti Y, Amiot L. Soluble HLA-G molecules impair natural killer/dendritic cell crosstalk via inhibition of dendritic cells. Eur J Immunol (2008) 38:742-9. doi:10.1002/eji.200736918

27. Agaugué S, Carosella ED, Rouas-Freiss N. Role of HLA-G in tumour escape through expansion of myeloid-derived suppressor cells and cytokinic balance in favor of TH2 versus TH1/TH17. Blood (2011) 117:7021-31. doi:10.1182/ blood-2010-07-294389

28. Bolton AE, Pockley AG, Clough KJ, Mowles EA, Stoker RJ, Westwood OM, et al. Identification of placental protein 14 as an immunosuppressive factor in human reproduction. Lancet (1987) 1:593-5. doi:10.1016/S0140-6736(87)90235-2
29. Scholz C, Heublein S, Lenhard M, Friese K, Mayr D, Jeschke U. Glycodelin a is a prognostic marker to predict poor outcome in advanced stage ovarian cancer patients. BMC Res Notes (2012) 5:551. doi:10.1186/1756-0500-5-551

30. Hautala LC, Greco D, Koistinen R, Heikkinen T, Heikkilä P, Aittomäki K, et al. Glycodelin expression associates with differential tumour phenotype and outcome in sporadic and familial non-brca $1 / 2$ breast cancer patients. Breast Cancer Res Treat (2011) 128:85-95. doi:10.1007/s10549-010-1065-y

31. Kunert-Keil C, Steinmüller F, Jeschke U, Gredes T, Gedrange T. Immunolocalization of glycodelin in human adenocarcinoma of the lung, squamous cell carcinoma of the lung and lung metastases of colonic adenocarcinoma. Acta Histochem (2011) 113:798-802. doi:10.1016/j.acthis.2010.11.009

32. Alok A, Karande AA. The role of glycodelin as an immune-modulating agent at the feto-maternal interface. J Reprod Immunol (2009) 83:124-7. doi:10.1016/j.jri.2009.06.261

33. Scholz C, Toth B, Brunnhuber R, Rampf E, Weissenbacher T, Santoso L, et al. Glycodelin a induces a tolerogenic phenotype in monocyte-derived dendritic cells in vitro. Am J Reprod Immunol (2008) 60:501-12. doi:10.1111/j.16000897.2008.00647.x

34. Lee C, Lam EYF, Lam KKW, Koistinen H, Seppälä M, Ng EHY, et al. Glycodelina stimulates interleukin-6 secretion by human monocytes and macrophages through L-selectin and the extracellular signal-regulated kinase pathway. J Biol Chem (2012) 287:36999-7009. doi:10.1074/jbc.M112.385336

35. Godin-Ethier J, Hanafi L, Piccirillo CA, Lapointe R. Indoleamine 2,3dioxygenase expression in human cancers: clinical and immunologic perspectives. Clin Cancer Res (2011) 17:6985-91. doi:10.1158/1078-0432.CCR-111331

36. Beavis PA, Stagg J, Darcy PK, Smyth MJ. Cd73: a potent suppressor of antitumour immune responses. Trends Immunol (2012) 33:231-7. doi:10.1016/j.it. 2012.02.009

37. Krüger-Krasagakes S, Krasagakis K, Garbe C, Schmitt E, Hüls C, Blankenstein T, et al. Expression of interleukin 10 in human melanoma. Br J Cancer (1994) 70:1182-5. doi:10.1038/bjc.1994.469

38. Kim J, Modlin RL, Moy RL, Dubinett SM, McHugh T, Nickoloff BJ, et al. IL10 production in cutaneous basal and squamous cell carcinomas. A mechanism for evading the local T cell immune response. J Immunol (1995) 155: $2240-7$.

39. Flavell RA, Sanjabi S, Wrzesinski SH, Licona-Limón P. The polarization of immune cells in the tumour environment by TGF-beta. Nat Rev Immunol (2010) 10:554-67. doi:10.1038/nri2808

40. Gabrilovich DI, Chen HL, Girgis KR, Cunningham HT, Meny GM, Nadaf S, et al. Production of vascular endothelial growth factor by human tumours inhibits the functional maturation of dendritic cells. Nat Med (1996) 2:1096-103. doi:10.1038/nm1096-1096

41. Kusmartsev S, Eruslanov E, Kübler H, Tseng T, Sakai Y, Su Z, et al. Oxidative stress regulates expression of VEGFR1 in myeloid cells: link to tumourinduced immune suppression in renal cell carcinoma. J Immunol (2008) 181: $346-53$.

42. Oyama T, Ran S, Ishida T, Nadaf S, Kerr L, Carbone DP, et al. Vascular endothelial growth factor affects dendritic cell maturation through the inhibition of nuclear factor-kappa b activation in hemopoietic progenitor cells. J Immunol (1998) 160:1224-32.

43. Menetrier-Caux C, Montmain G, Dieu MC, Bain C, Favrot MC, Caux C, et al. Inhibition of the differentiation of dendritic cells from CD34(+) progenitors by tumour cells: role of interleukin- 6 and macrophage colony-stimulating factor. Blood (1998) 92:4778-91.

44. Kobie JJ, Wu RS, Kurt RA, Lou S, Adelman MK, Whitesell LJ, et al. Transforming growth factor beta inhibits the antigen-presenting functions and antitumour activity of dendritic cell vaccines. Cancer Res (2003) 63:1860-4.

45. Sato K, Kawasaki H, Nagayama H, Enomoto M, Morimoto C, Tadokoro K, et al. TGF-beta 1 reciprocally controls chemotaxis of human peripheral blood monocyte-derived dendritic cells via chemokine receptors. J Immunol (2000) 164:2285-95.

46. Ronger-Savle S, Valladeau J, Claudy A, Schmitt D, Peguet-Navarro J, DezutterDambuyant C, et al. TGFbeta inhibits CD1D expression on dendritic cells. J Invest Dermatol (2005) 124:116-8. doi:10.1111/j.0022-202X.2004.23315.x

47. Dudziak D, Nimmerjahn F, Bornkamm GW, Laux G. Alternative splicing generates putative soluble $\mathrm{CD} 83$ proteins that inhibit $\mathrm{T}$ cell proliferation. J Immunol (2005) 174:6672-6. 
48. Baleeiro RB, Barbuto JAM. Local secretion/shedding of tumour-derived CD83 molecules as a novel tumour escape mechanism. Mol Immunol (2008) 45:3502-4. doi:10.1016/j.molimm.2008.04.005

49. Hock BD, Haring LF, Steinkasserer A, Taylor KG, Patton WN, McKenzie JL. The soluble form of CD83 is present at elevated levels in a number of hematological malignancies. Leuk Res (2004) 28:237-41. doi:10.1016/S0145-2126(03) 00255-8

50. Hock BD, Fernyhough LJ, Gough SM, Steinkasserer A, Cox AG, McKenzie JL. Release and clinical significance of soluble CD83 in chronic lymphocytic leukemia. Leuk Res (2009) 33:1089-95. doi:10.1016/j.leukres.2009.01.001

51. Bock F, Rössner S, Onderka J, Lechmann M, Pallotta MT, Fallarino F, et al. Topical application of soluble CD83 induces IDO-mediated immune modulation, increases foxp3+ T cells, and prolongs allogeneic corneal graft survival. J Immunol (2013) 191:1965-75. doi:10.4049/jimmunol.1201531

52. Cook RS, Jacobsen KM, Wofford AM, Deryckere D, Stanford J, Prieto AL, et al. MerTK inhibition in tumour leukocytes decreases tumour growth and metastasis. J Clin Invest (2013) 123:3231-42. doi:10.1172/JCI67655

53. Bergenfelz C, Janols H, Wullt M, Jirström K, Bredberg A, Leandersson K. Wnt5a inhibits human monocyte-derived myeloid dendritic cell generation. Scand J Immunol (2013) 78:194-204. doi:10.1111/sji.12075

54. Oderup C, LaJevic M, Butcher EC. Canonical and noncanonical Wnt proteins program dendritic cell responses for tolerance. J Immunol (2013) 190:6126-34. doi:10.4049/jimmunol.1203002

55. Valencia J, Hernández-López C, Martínez VG, Hidalgo L, Zapata AG, Vicente Á, et al. Wnt5a skews dendritic cell differentiation to an unconventional phenotype with tolerogenic features. JImmunol (2011) 187:4129-39. doi:10.4049/ jimmunol.1101243

56. Hack K, Reilly L, Proby C, Fleming C, Leigh I, Foerster J. Wnt5a inhibits the CPG oligodeoxynucleotide-triggered activation of human plasmacytoid dendritic cells. Clin Exp Dermatol (2012) 37:557-61. doi:10.1111/j.1365-2230. 2012.04362.x

57. Ishida A, Ohta M, Toda M, Murata T, Usui T, Akita K, et al. Mucin-induced apoptosis of monocyte-derived dendritic cells during maturation. Proteomics (2008) 8:3342-9. doi:10.1002/pmic.200800039

58. Monti P, Leone BE, Zerbi A, Balzano G, Cainarca S, Sordi V, et al. Tumourderived mucl mucins interact with differentiating monocytes and induce IL10highil-12low regulatory dendritic cell. J Immunol (2004) 172:7341-9.

59. Ohta M, Ishida A, Toda M, Akita K, Inoue M, Yamashita K, et al. Immunomodulation of monocyte-derived dendritic cells through ligation of tumourproduced mucins to Siglec-9. Biochem Biophys Res Commun (2010) 402:663-9. doi:10.1016/j.bbrc.2010.10.079

60. Rughetti A, Pellicciotta I, Biffoni M, Bäckström M, Link T, Bennet EP, et al. Recombinant tumour-associated MUC1 glycoprotein impairs the differentiation and function of dendritic cells. J Immunol (2005) 174:7764-72.

61. Jonuleit H, Kühn U, Müller G, Steinbrink K, Paragnik L, Schmitt E, et al. Pro-inflammatory cytokines and prostaglandins induce maturation of potent immunostimulatory dendritic cells under fetal calf serum-free conditions. Eur J Immunol (1997) 27:3135-42. doi:10.1002/eji.1830271209

62. Scandella E, Men Y, Gillessen S, Förster R, Groettrup M. Prostaglandin E2 is a key factor for ccr7 surface expression and migration of monocytederived dendritic cells. Blood (2002) 100:1354-61. doi:10.1182/blood-200111-0017

63. Krause P, Bruckner M, Uermösi C, Singer E, Groettrup M, Legler DF. Prostaglandin E(2) enhances T-cell proliferation by inducing the costimulatory molecules ox401, cd70, and 4-1BBL on dendritic cells. Blood (2009) 113:2451-60. doi:10.1182/blood-2008-05-157123

64. Arimoto-Miyamoto K, Kadowaki N, Kitawaki T, Iwata S, Morimoto C, Uchiyama T. Optimal stimulation for CD70 induction on human monocytederived dendritic cells and the importance of CD70 in naive CD4(+) T-cell differentiation. Immunology (2010) 130:137-49. doi:10.1111/j.1365-2567.2010. 03220.x

65. Vieira PL, de Jong EC, Wierenga EA, Kapsenberg ML, Kalinski P. Development of TH1-inducing capacity in myeloid dendritic cells requires environmental instruction. J Immunol (2000) 164:4507-12.

66. Khayrullina T, Yen J, Jing H, Ganea D. In vitro differentiation of dendritic cells in the presence of prostaglandin e 2 alters the IL-12/IL-23 balance and promotes differentiation of Th17 cells. J Immunol (2008) 181:721-35.
67. Langowski JL, Zhang X, Wu L, Mattson JD, Chen T, Smith K, et al. IL-23 promotes tumour incidence and growth. Nature (2006) 442:461-5. doi:10.1038/ nature 04808

68. Teng MWL, Vesely MD, Duret H, McLaughlin N, Towne JE, Schreiber RD, et al. Opposing roles for IL-23 and IL-12 in maintaining occult cancer in an equilibrium state. Cancer Res (2012) 72:3987-96. doi:10.1158/0008-5472.CAN-121337

69. Mao Y, Poschke I, Wennerberg E, Pico de Coaña Y, Egyhazi Brage S, Schultz I, et al. Melanoma-educated CD14+ cells acquire a myeloid-derived suppressor cell phenotype through COX-2-dependent mechanisms. Cancer Res (2013) 73:3877-87. doi:10.1158/0008-5472.CAN-12-4115

70. von Bergwelt-Baildon MS, Popov A, Saric T, Chemnitz J, Classen S, Stoffel MS, et al. CD25 and indoleamine 2,3-dioxygenase are up-regulated by prostaglandin E2 and expressed by tumour-associated dendritic cells in vivo: additional mechanisms of T-cell inhibition. Blood (2006) 108:228-37. doi:10. 1182/blood-2005-08-3507

71. Van Elssen CHMJ, Vanderlocht J, Oth T, Senden-Gijsbers BLMG, Germeraad WTV, Bos GMJ. Inflammation-restraining effects of prostaglandin E2 on natural killer-dendritic cell (NK-DC) interaction are imprinted during dc maturation. Blood (2011) 118:2473-82. doi:10.1182/blood-2010-09-307835

72. Poloso NJ, Urquhart P, Nicolaou A, Wang J, Woodward DF. PGE2 differentially regulates monocyte-derived dendritic cell cytokine responses depending on receptor usage (EP2/EP4). Mol Immunol (2013) 54:284-95. doi:10.1016/j. molimm.2012.12.010

73. Shimabukuro-Vornhagen A, Liebig TM, Koslowsky T, Theurich S, von Bergwelt-Baildon MS. The ratio between dendritic cells and T cells determines whether prostaglandin E2 has a stimulatory or inhibitory effect. Cell Immunol (2013) 281:62-7. doi:10.1016/j.cellimm.2013.01.001

74. Bennaceur K, Popa I, Portoukalian J, Berthier-Vergnes O, Péguet-Navarro J. Melanoma-derived gangliosides impair migratory and antigen-presenting function of human epidermal Langerhans cells and induce their apoptosis. Int Immunol (2006) 18:879-86. doi:10.1093/intimm/dxl024

75. Bennaceur K, Popa I, Chapman JA, Migdal C, Péguet-Navarro J, Touraine J, et al. Different mechanisms are involved in apoptosis induced by melanoma gangliosides on human monocyte-derived dendritic cells. Glycobiology (2009) 19:576-82. doi:10.1093/glycob/cwp015

76. Péguet-Navarro J, Sportouch M, Popa I, Berthier O, Schmitt D, Portoukalian J. Gangliosides from human melanoma tumours impair dendritic cell differentiation from monocytes and induce their apoptosis. J Immunol (2003) 170:3488-94.

77. Shurin GV, Shurin MR, Bykovskaia S, Shogan J, Lotze MT, Barksdale EMJ. Neuroblastoma-derived gangliosides inhibit dendritic cell generation and function. Cancer Res (2001) 61:363-9.

78. Wölfl M, Batten WY, Posovszky C, Bernhard H, Berthold F. Gangliosides inhibit the development from monocytes to dendritic cells. Clin Exp Immunol (2002) 130:441-8. doi:10.1046/j.1365-2249.2002.02006.x

79. Tourkova IL, Shurin GV, Chatta GS, Perez L, Finke J, Whiteside TL, et al. Restoration by IL-15 of MHC class I antigen-processing machinery in human dendritic cells inhibited by tumour-derived gangliosides. J Immunol (2005) 175:3045-52.

80. Tourkova IL, Shurin GV, Ferrone S, Shurin MR. Interferon regulatory factor 8 mediates tumour-induced inhibition of antigen processing and presentation by dendritic cells. Cancer Immunol Immunother (2009) 58:567-74. doi:10.1007/s00262-008-0579-1

81. Heitger A, Ladisch S. Gangliosides block antigen presentation by human monocytes. Biochim Biophys Acta (1996) 1303:161-8. doi:10.1016/0005-2760(96) 00091-4

82. Caldwell S, Heitger A, Shen W, Liu Y, Taylor B, Ladisch S. Mechanisms of ganglioside inhibition of APC function. J Immunol (2003) 171:1676-83.

83. van Cruijsen H, Ruiz MG, van der Valk P, de Gruijl TD, Giaccone G. Tissue micro array analysis of ganglioside $\mathrm{N}$-glycolyl GM3 expression and signal transducer and activator of transcription (STAT)-3 activation in relation to dendritic cell infiltration and microvessel density in non-small cell lung cancer. BMC Cancer (2009) 9:180. doi:10.1186/1471-2407-9-180

84. Nefedova Y, Huang M, Kusmartsev S, Bhattacharya R, Cheng P, Salup R, et al. Hyperactivation of STAT3 is involved in abnormal differentiation of dendritic cells in cancer. J Immunol (2004) 172:464-74. 
85. Yu H, Kortylewski M, Pardoll D. Crosstalk between cancer and immune cells: role of STAT3 in the tumour microenvironment. Nat Rev Immunol (2007) 7:41-51. doi:10.1038/nri1995

86. Hoentjen F, Sartor RB, Ozaki M, Jobin C. STAT3 regulates NF-kappaB recruitment to the IL-12p40 promoter in dendritic cells. Blood (2005) 105:689-96. doi:10.1182/blood-2004-04-1309

87. Zhao F, Falk C, Osen W, Kato M, Schadendorf D, Umansky V. Activation of p38 mitogen-activated protein kinase drives dendritic cells to become tolerogenic in ret transgenic mice spontaneously developing melanoma. Clin Cancer Res (2009) 15:4382-90. doi:10.1158/1078-0432.CCR-09-0399

88. Huang G, Wang Y, Vogel P, Kanneganti T, Otsu K, Chi H. Signaling via the kinase p38 $\alpha$ programs dendritic cells to drive TH17 differentiation and autoimmune inflammation. Nat Immunol (2012) 13:152-61. doi:10.1038/ni.2207

89. Loges S, Schmidt T, Tjwa M, van Geyte K, Lievens D, Lutgens E, et al. Malignant cells fuel tumour growth by educating infiltrating leukocytes to produce the mitogen GAS6. Blood (2010) 115:2264-73. doi:10.1182/blood-2009-06228684

90. Caiado F, Carvalho T, Rosa I, Remédio L, Costa A, Matos J, et al. Bone marrowderived CD11B+JAGGED2+ cells promote epithelial-to-mesenchymal transition and metastasization in colorectal cancer. Cancer Res (2013) 73:4233-46. doi:10.1158/0008-5472.CAN-13-0085

91. Murdoch C, Muthana M, Coffelt SB, Lewis CE. The role of myeloid cells in the promotion of tumour angiogenesis. Nat Rev Cancer (2008) 8:618-31. doi: $10.1038 / \mathrm{nrc} 2444$

92. Riboldi E, Musso T, Moroni E, Urbinati C, Bernasconi S, Rusnati M, et al. Cutting edge: proangiogenic properties of alternatively activated dendritic cells. J Immunol (2005) 175:2788-92.

93. Hartmann E, Wollenberg B, Rothenfusser S, Wagner M, Wellisch D, Mack B, et al. Identification and functional analysis of tumour-infiltrating plasmacytoid dendritic cells in head and neck cancer. Cancer Res (2003) 63:6478-87.

94. Jensen TO, Schmidt H, Møller HJ, Donskov F, Høyer M, Sjoegren P, et al. Intratumoural neutrophils and plasmacytoid dendritic cells indicate poor prognosis and are associated with PSTAT3 expression in AJCC stage I/II melanoma. Cancer (2012) 118:2476-85. doi:10.1002/cncr.26511

95. Labidi-Galy SI, Sisirak V, Meeus P, Gobert M, Treilleux I, Bajard A, et al. Quantitative and functional alterations of plasmacytoid dendritic cells contribute to immune tolerance in ovarian cancer. Cancer Res (2011) 71:5423-34. doi:10.1158/0008-5472.CAN-11-0367

96. Treilleux I, Blay J, Bendriss-Vermare N, Ray-Coquard I, Bachelot T, Guastalla J, et al. Dendritic cell infiltration and prognosis of early stage breast cancer. Clin Cancer Res (2004) 10:7466-74. doi:10.1158/1078-0432.CCR-04-0684

97. Charles J, Di Domizio J, Salameire D, Bendriss-Vermare N, Aspord C, Muhammad R, et al. Characterization of circulating dendritic cells in melanoma: role of CCR6 in plasmacytoid dendritic cell recruitment to the tumour. J Invest Dermatol (2010) 130:1646-56. doi:10.1038/jid.2010.24

98. Vermi W, Bonecchi R, Facchetti F, Bianchi D, Sozzani S, Festa S, et al. Recruitment of immature plasmacytoid dendritic cells (plasmacytoid monocytes) and myeloid dendritic cells in primary cutaneous melanomas. J Pathol (2003) 200:255-68. doi:10.1002/path.1344

99. Zou W, Machelon V, Coulomb-L'Hermin A, Borvak J, Nome F, Isaeva T, et al. Stromal-derived factor- 1 in human tumours recruits and alters the function of plasmacytoid precursor dendritic cells. Nat Med (2001) 7:1339-46. doi:10.1038/nm1201-1339

100. Bekeredjian-Ding I, Schäfer M, Hartmann E, Pries R, Parcina M, Schneider $\mathrm{P}$, et al. Tumour-derived prostaglandin e and transforming growth factorbeta synergize to inhibit plasmacytoid dendritic cell-derived interferon-alpha. Immunology (2009) 128:439-50. doi:10.1111/j.1365-2567.2009.03134.x

101. Duramad O, Fearon KL, Chan JH, Kanzler H, Marshall JD, Coffman $\mathrm{RL}$, et al. IL-10 regulates plasmacytoid dendritic cell response to CPGcontaining immunostimulatory sequences. Blood (2003) 102:4487-92. doi:10. 1182/blood-2003-07-2465

102. Fabricius D, Neubauer M, Mandel B, Schütz C, Viardot A, Vollmer A, et al. Prostaglandin E2 inhibits IFN-alpha secretion and TH1 costimulation by human plasmacytoid dendritic cells via E-prostanoid 2 and E-prostanoid 4 receptor engagement. J Immunol (2010) 184:677-84. doi:10.4049/jimmunol. 0902028

103. Sisirak V, Vey N, Goutagny N, Renaudineau S, Malfroy M, Thys S, et al. Breast cancer-derived transforming growth factor- $\beta$ and tumour necrosis factor- $\alpha$ compromise interferon- $\alpha$ production by tumour-associated plasmacytoid dendritic cells. Int J Cancer (2013) 133:771-8. doi:10.1002/ijc.28072

104. Son Y, Ito T, Ozaki Y, Tanijiri T, Yokoi T, Nakamura K, et al. Prostaglandin E2 is a negative regulator on human plasmacytoid dendritic cells. Immunology (2006) 119:36-42. doi:10.1111/j.1365-2567.2006.02402.x

105. Tsukamoto N, Okada S, Onami Y, Sasaki Y, Umezawa K, Kawakami Y. Impairment of plasmacytoid dendritic cells for IFN production by the ligand for immunoglobulin-like transcript 7 expressed on human cancer cells. Clin Cancer Res (2009) 15:5733-43. doi:10.1158/1078-0432.CCR-09-0171

106. Cao W, Rosen DB, Ito T, Bover L, Bao M, Watanabe G, et al. Plasmacytoid dendritic cell-specific receptor ILT7-FC epsilonRI gamma inhibits tolllike receptor-induced interferon production. J Exp Med (2006) 203:1399-405. doi:10.1084/jem.20052454

107. Watkins SK, Zhu Z, Riboldi E, Shafer-Weaver KA, Stagliano KER, Sklavos MM, et al. Foxo3 programs tumour-associated DCS to become tolerogenic in human and murine prostate cancer. J Clin Invest (2011) 121:1361-72. doi:10.1172/JCI44325

108. Ito T, Yang M, Wang Y, Lande R, Gregorio J, Perng OA, et al. Plasmacytoid dendritic cells prime IL-10-producing T regulatory cells by inducible costimulator ligand. J Exp Med (2007) 204:105-15. doi:10.1084/jem.20061660

109. Moseman EA, Liang X, Dawson AJ, Panoskaltsis-Mortari A, Krieg AM, Liu $\mathrm{Y}$, et al. Human plasmacytoid dendritic cells activated by CPG oligodeoxynucleotides induce the generation of CD4+CD25+ regulatory T cells. J Immunol (2004) 173:4433-42.

110. Ogata M, Ito T, Shimamoto K, Nakanishi T, Satsutani N, Miyamoto R, et al. Plasmacytoid dendritic cells have a cytokine-producing capacity to enhance ICOS ligand-mediated IL-10 production during T-cell priming. Int Immunol (2013) 25:171-82. doi:10.1093/intimm/dxs103

111. Gilliet M, Liu Y. Generation of human CD8 T regulatory cells by CD40 ligand-activated plasmacytoid dendritic cells. J Exp Med (2002) 195:695-704. doi:10.1084/jem.20011603

112. Wei S, Kryczek I, Zou L, Daniel B, Cheng P, Mottram P, et al. Plasmacytoid dendritic cells induce CD8+ regulatory $\mathrm{T}$ cells in human ovarian carcinoma. Cancer Res (2005) 65:5020-6. doi:10.1158/0008-5472.CAN-04-4043

113. Sisirak V, Faget J, Gobert M, Goutagny N, Vey N, Treilleux I, et al. Impaired IFN- $\alpha$ production by plasmacytoid dendritic cells favors regulatory T-cell expansion that may contribute to breast cancer progression. Cancer Res (2012) 72:5188-97. doi:10.1158/0008-5472.CAN-11-3468

114. Janke M, Witsch EJ, Mages HW, Hutloff A, Kroczek RA. Eminent role of ICOS costimulation for T cells interacting with plasmacytoid dendritic cells. Immunology (2006) 118:353-60. doi:10.1111/j.1365-2567.2006.02379.x

115. Conrad C, Gregorio J, Wang Y, Ito T, Meller S, Hanabuchi S, et al. Plasmacytoid dendritic cells promote immunosuppression in ovarian cancer via ICOS costimulation of FOXP3(+) T-regulatory cells. Cancer Res (2012) 72:5240-9. doi:10.1158/0008-5472.CAN-12-2271

116. Faget J, Bendriss-Vermare N, Gobert M, Durand I, Olive D, Biota C, et al. Icos-ligand expression on plasmacytoid dendritic cells supports breast cancer progression by promoting the accumulation of immunosuppressive CD4+ T cells. Cancer Res (2012) 72:6130-41. doi:10.1158/0008-5472.CAN12-2409

117. Fallarino F, Asselin-Paturel C, Vacca C, Bianchi R, Gizzi S, Fioretti MC, et al. Murine plasmacytoid dendritic cells initiate the immunosuppressive path way of tryptophan catabolism in response to CD200 receptor engagement. J Immunol (2004) 173:3748-54.

118. Puccetti P, Fallarino F. Generation of T cell regulatory activity by plasmacytoid dendritic cells and tryptophan catabolism. Blood Cells Mol Dis (2008) 40:101-5. doi:10.1016/j.bcmd.2007.06.026

119. Chen W, Liang X, Peterson AJ, Munn DH, Blazar BR. The indoleamine 2,3-dioxygenase pathway is essential for human plasmacytoid dendritic cellinduced adaptive T regulatory cell generation. J Immunol (2008) 181:5396-404.

120. Gerlini G, Di Gennaro P, Mariotti G, Urso C, Chiarugi A, Pimpinelli N, et al. Indoleamine 2,3-dioxygenase+ cells correspond to the BDCA2+ plasmacytoid dendritic cells in human melanoma sentinel nodes. J Invest Dermatol (2010) 130:898-901. doi:10.1038/jid.2009.307

121. Munn DH, Sharma MD, Hou D, Baban B, Lee JR, Antonia SJ, et al. Expression of indoleamine 2,3-dioxygenase by plasmacytoid dendritic cells in tumour-draining lymph nodes. J Clin Invest (2004) 114:280-90. doi:10.1172/ JCI21583E1 
122. Sharma MD, Baban B, Chandler P, Hou D, Singh N, Yagita H, et al. Plasmacytoid dendritic cells from mouse tumour-draining lymph nodes directly activate mature tregs via indoleamine 2,3-dioxygenase. J Clin Invest (2007) 117:2570-82. doi:10.1172/JCI31911

123. Kassner N, Krueger M, Yagita H, Dzionek A, Hutloff A, Kroczek R, et al. Cutting edge: plasmacytoid dendritic cells induce IL-10 production in T cells via the delta-like-4/notch axis. J Immunol (2010) 184:550-4. doi:10.4049/jimmunol. 0903152

124. Fabricius D, Nußbaum B, Busch D, Panitz V, Mandel B, Vollmer A, et al. Antiviral vaccines license $\mathrm{T}$ cell responses by suppressing granzyme B levels in human plasmacytoid dendritic cells. J Immunol (2013) 191:1144-53. doi:10.4049/jimmunol.1203479

125. Jahrsdörfer B, Vollmer A, Blackwell SE, Maier J, Sontheimer K, Beyer T, et al. Granzyme B produced by human plasmacytoid dendritic cells suppresses T-cell expansion. Blood (2010) 115:1156-65. doi:10.1182/blood-2009-07235382

126. Curiel TJ, Cheng P, Mottram P, Alvarez X, Moons L, Evdemon-Hogan M, et al. Dendritic cell subsets differentially regulate angiogenesis in human ovarian cancer. Cancer Res (2004) 64:5535-8. doi:10.1158/0008-5472.CAN-04- 1272

127. Sawant A, Hensel JA, Chanda D, Harris BA, Siegal GP, Maheshwari A, et al. Depletion of plasmacytoid dendritic cells inhibits tumour growth and prevents bone metastasis of breast cancer cells. J Immunol (2012) 189:4258-65. doi:10.4049/jimmunol.1101855

128. Wang S, Hong S, Yang J, Qian J, Zhang X, Shpall E, et al. Optimizing immunotherapy in multiple myeloma: restoring the function of patients' monocyte-derived dendritic cells by inhibiting p38 or activating MEK/ERK MAPK and neutralizing interleukin-6 in progenitor cells. Blood (2006) 108:4071-7. doi:10.1182/blood-2006-04-016980

129. Brady MT, Miller A, Sait SN, Ford LA, Minderman H, Wang ES, et al. Downregulation of signal transducer and activator of transcription 3 improves human acute myeloid leukemia-derived dendritic cell function. Leuk Res (2013) 37:822-8. doi:10.1016/j.leukres.2013.04.002

130. Mailliard RB, Wankowicz-Kalinska A, Cai Q, Wesa A, Hilkens CM, Kapsenberg ML, et al. Alpha-type-1 polarized dendritic cells: a novel immunization tool with optimized CTL-inducing activity. Cancer Res (2004) 64:5934-7. doi:10.1158/0008-5472.CAN-04-1261

131. Akiyama Y, Oshita C, Kume A, Iizuka A, Miyata H, Komiyama M, et al. $\alpha$-type1 polarized dendritic cell-based vaccination in recurrent high-grade glioma: a phase I clinical trial. BMC Cancer (2012) 12:623. doi:10.1186/1471-2407-12623

132. Okada H, Kalinski P, Ueda R, Hoji A, Kohanbash G, Donegan TE, et al. Induction of cd8+ T-cell responses against novel glioma-associated antigen peptides and clinical activity by vaccinations with \{alpha\}-type 1 polarized dendritic cells and polyinosinic-polycytidylic acid stabilized by lysine and carboxymethylcellulose in patients with recurrent malignant glioma. J Clin Oncol (2011) 29:330-6. doi:10.1200/JCO.2010.30.7744

133. Czerniecki BJ, Koski GK, Koldovsky U, Xu S, Cohen PA, Mick R, et al. Targeting her-2/neu in early breast cancer development using dendritic cells with staged interleukin-12 burst secretion. Cancer Res (2007) 67:1842-52. doi:10.1158/0008-5472.CAN-06-4038

134. Koski GK, Koldovsky U, Xu S, Mick R, Sharma A, Fitzpatrick E, et al. A novel dendritic cell-based immunization approach for the induction of durable TH1-polarized anti-her-2/neu responses in women with early breast cancer. J Immunother (2012) 35:54-65. doi:10.1097/CJI.0b013e318235f512

135. Nakamoto Y, Mizukoshi E, Kitahara M, Arihara F, Sakai Y, Kakinoki K, et al. Prolonged recurrence-free survival following OK432-stimulated dendritic cell transfer into hepatocellular carcinoma during transarterial embolization. Clin Exp Immunol (2011) 163:165-77. doi:10.1111/j.1365-2249.2010.04246.x

136. Sakakibara M, Kanto T, Hayakawa M, Kuroda S, Miyatake H, Itose I, et al. Comprehensive immunological analyses of colorectal cancer patients in the phase I/II study of quickly matured dendritic cell vaccine pulsed with carcinoembryonic antigen peptide. Cancer Immunol Immunother (2011) 60:1565-75. doi:10.1007/s00262-011-1051-1

137. Papewalis C, Jacobs B, Wuttke M, Ullrich E, Baehring T, Fenk R, et al. IFN-alpha skews monocytes into CD56+-expressing dendritic cells with potent functional activities in vitro and in vivo. J Immunol (2008) 180:1462-70.

138. Romano E, Rossi M, Ratzinger G, de Cos M, Chung DJ, Panageas KS, et al. Peptide-loaded Langerhans cells, despite increased IL15 secretion and T-cell activation in vitro, elicit antitumour T-cell responses comparable to peptideloaded monocyte-derived dendritic cells in vivo. Clin Cancer Res (2011) 17:1984-97. doi:10.1158/1078-0432.CCR-10-3421

139. Franks HA, Wang Q, Lax SJ, Collins MK, Escors D, Patel PM, et al. Novel function for the p38-MK2 signaling pathway in circulating CD1c+ (BDCA-1+) myeloid dendritic cells from healthy donors and advanced cancer patients; inhibition of p38 enhances IL-12 whilst suppressing IL-10. Int J Cancer (2013). 134:575-86. doi:10.1002/ijc.28398

140. Aspord C, Charles J, Leccia M, Laurin D, Richard M, Chaperot L, et al. A novel cancer vaccine strategy based on hla-a ${ }^{\star} 0201$ matched allogeneic plasmacytoid dendritic cells. PLoS One (2010) 5:e10458. doi:10.1371/journal.pone.0010458

141. Aspord C, Leccia M, Salameire D, Laurin D, Chaperot L, Charles J, et al. HLA$\left.\mathrm{a}^{*}\right) 0201(+)$ plasmacytoid dendritic cells provide a cell-based immunotherapy for melanoma patients. J Invest Dermatol (2012) 132:2395-406. doi:10.1038/ jid.2012.152

142. Tel J, Aarntzen EHJG, Baba T, Schreibelt G, Schulte BM, Benitez-Ribas D, et al. Natural human plasmacytoid dendritic cells induce antigen-specific Tcell responses in melanoma patients. Cancer Res (2013) 73:1063-75. doi:10. 1158/0008-5472.CAN-12-2583

143. Vari F, Munster DJ, Hsu JL, Rossetti TR, Mahler SM, Gray PP, et al. Practical blood dendritic cell vaccination for immunotherapy of multiple myeloma. $\mathrm{Br}$ J Haematol (2008) 143:374-7. doi:10.1111/j.1365-2141.2008.07346.x

144. Small EJ, Fratesi P, Reese DM, Strang G, Laus R, Peshwa MV, et al. Immunotherapy of hormone-refractory prostate cancer with antigen-loaded dendritic cells. J Clin Oncol (2000) 18:3894-903.

145. Small EJ, Schellhammer PF, Higano CS, Redfern CH, Nemunaitis JJ, Valone FH, et al. Placebo-controlled phase iii trial of immunologic therapy with sipuleucel$\mathrm{T}$ (apc8015) in patients with metastatic, asymptomatic hormone refractory prostate cancer. J Clin Oncol (2006) 24:3089-94. doi:10.1200/JCO.2005.04. 5252

146. Tian F, Wang L, Qin W, Wang F, Song B, Li Y, et al. Vaccination with transforming growth factor-beta insensitive dendritic cells suppresses pulmonary metastases of renal carcinoma in mice. Cancer Lett (2008) 271:333-41. doi:10.1016/j.canlet.2008.06.025

147. Wang F, Qin W, Wen W, Tian F, Song B, Zhang Q, et al. TGF-beta insensitive dendritic cells: an efficient vaccine for murine prostate cancer. Cancer Immunol Immunother (2007) 56:1785-93. doi:10.1007/s00262-007-0322-3

148. Hwang W, Jung K, Jeon Y, Yun S, Kim TW, Choi I. Knockdown of the interleukin-6 receptor alpha chain of dendritic cell vaccines enhances the therapeutic potential against IL-6 producing tumours. Vaccine (2010) 29:34-44. doi:10.1016/j.vaccine.2010.10.027

149. Iwata-Kajihara T, Sumimoto H, Kawamura N, Ueda R, Takahashi T, Mizuguchi $\mathrm{H}$, et al. Enhanced cancer immunotherapy using STAT3-depleted dendritic cells with high TH1-inducing ability and resistance to cancer cell-derived inhibitory factors. J Immunol (2011) 187:27-36. doi:10.4049/jimmunol. 1002067

150. Nefedova Y, Gabrilovich DI. Targeting of JAK/STAT pathway in antigen presenting cells in cancer. Curr Cancer Drug Targets (2007) 7:71-7. doi:10.2174/ 156800907780006887

151. Chen Y, Man K, Ling GS, Chen Y, Sun B, Cheng Q, et al. A crucial role for dendritic cell (DC) IL-10 in inhibiting successful DC-based immunotherapy: superior antitumour immunity against hepatocellular carcinoma evoked by dc devoid of IL-10. J Immunol (2007) 179:6009-15.

152. Liu G, Ng H, Akasaki Y, Yuan X, Ehtesham M, Yin D, et al. Small interference RNA modulation of IL-10 in human monocyte-derived dendritic cells enhances the TH1 response. Eur J Immunol (2004) 34:1680-7. doi:10.1002/eji. 200425081

153. Pruitt SK, Boczkowski D, de Rosa N, Haley NR, Morse MA, Tyler DS, et al. Enhancement of anti-tumour immunity through local modulation of CTLA-4 and GITR by dendritic cells. Eur J Immunol (2011) 41:3553-63. doi:10.1002/eji.201141383

154. Bak SP, Barnkob MS, Bai A, Higham EM, Wittrup KD, Chen J. Differential requirement for CD70 and CD80/CD86 in dendritic cell-mediated activation of tumour-tolerized CD8 T cells. J Immunol (2012) 189:1708-16. doi:10.4049/jimmunol.1201271

155. Pen JJ, De Keersmaecker B, Maenhout SK, Van Nuffel AMT, Heirman C, Corthals J, et al. Modulation of regulatory $\mathrm{T}$ cell function by monocyte-derived dendritic cells matured through electroporation with MRNA encoding CD40 
ligand, constitutively active TLR4, and CD70. J Immunol (2013) 191:1976-83. doi:10.4049/jimmunol.1201008

156. Keller AM, Schildknecht A, Xiao Y, van den Broek M, Borst J. Expression of costimulatory ligand CD70 on steady-state dendritic cells breaks CD8+ T cell tolerance and permits effective immunity. Immunity (2008) 29:934-46. doi:10.1016/j.immuni.2008.10.009

157. Bonehill A, Tuyaerts S, Van Nuffel AMT, Heirman C, Bos TJ, Fostier K, et al. Enhancing the T-cell stimulatory capacity of human dendritic cells by coelectroporation with CD401, CD70 and constitutively active TLR4 encoding MRNA. Mol Ther (2008) 16:1170-80. doi:10.1038/mt.2008.77

158. Stephens GL, McHugh RS, Whitters MJ, Young DA, Luxenberg D, Carreno BM, et al. Engagement of glucocorticoid-induced TNFR family-related receptor on effector $\mathrm{T}$ cells by its ligand mediates resistance to suppression by CD4+CD25+ T cells. J Immunol (2004) 173:5008-20.

159. Wilgenhof S, Van Nuffel AMT, Corthals J, Heirman C, Tuyaerts S, Benteyn D, et al. Therapeutic vaccination with an autologous mRNA electroporated dendritic cell vaccine in patients with advanced melanoma. J Immunother (2011) 34:448-56. doi:10.1097/CJI.0b013e31821dcb31

160. Van Nuffel AMT, Benteyn D, Wilgenhof S, Corthals J, Heirman C, Neyns B, et al. Intravenous and intradermal trimix-dendritic cell therapy results in a broad T-cell response and durable tumour response in a chemorefractory stage IV-M1C melanoma patient. Cancer Immunol Immunother (2012) 61:1033-43. doi:10.1007/s00262-011-1176-2

161. Lipscomb MW, Chen L, Taylor JL, Goldbach C, Watkins SC, Kalinski P, et al. Ectopic T-bet expression licenses dendritic cells for IL-12-independent priming of type 1 T cells in vitro. J Immunol (2009) 183:7250-8. doi:10.4049/jimmunol. 0901477

162. Qu Y, Chen L, Pardee AD, Taylor JL, Wesa AK, Storkus WJ. Intralesional delivery of dendritic cells engineered to express T-bet promotes protective type 1 immunity and the normalization of the tumour microenvironment. J Immunol (2010) 185:2895-902. doi:10.4049/jimmunol.1001294

163. Song X, Evel-Kabler K, Shen L, Rollins L, Huang XF, Chen S. A20 is an antigen presentation attenuator, and its inhibition overcomes regulatory $\mathrm{T}$ cellmediated suppression. Nat Med (2008) 14:258-65. doi:10.1038/nm1721

164. Turner ML, Schnorfeil FM, Brocker T. MicroRNAs regulate dendritic cell differentiation and function. J Immunol (2011) 187:3911-7. doi:10.4049/jimmunol. 1101137

165. Min S, Liang X, Zhang M, Zhang Y, Mei S, Liu J, et al. Multiple tumourassociated microRNAs modulate the survival and longevity of dendritic cells by targeting YWHAZ and BCL2 signaling pathways. J Immunol (2013) 190:2437-46. doi:10.4049/jimmunol.1202282

166. Galluzzi L, Vacchelli E, Eggermont A, Fridman WH, Galon J, Sautès-Fridman C, et al. Trial watch: experimental toll-like receptor agonists for cancer therapy. Onco Immunol (2012) 1:699-716. doi:10.4161/onci.20696

167. Bacher N, Raker V, Hofmann C, Graulich E, Schwenk M, Baumgrass R, et al. Interferon- $\alpha$ suppresses camp to disarm human regulatory $\mathrm{T}$ cells. Cancer Res (2013) 73:5647-56. doi:10.1158/0008-5472.CAN-12-3788

168. Chaperot L, Blum A, Manches O, Lui G, Angel J, Molens J, et al. Virus or TLR agonists induce trail-mediated cytotoxic activity of plasmacytoid dendritic cells. J Immunol (2006) 176:248-55.

169. Drobits B, Holcmann M, Amberg N, Swiecki M, Grundtner R, Hammer M, et al. Imiquimod clears tumours in mice independent of adaptive immunity by converting PDCS into tumour-killing effector cells. J Clin Invest (2012) 122:575-85. doi:10.1172/JCI61034

170. Shirota H, Klinman DM. Effect of CPG ODN on monocytic myeloid derived suppressor cells. Onco Immunol (2012) 1:780-2. doi:10.4161/onci.19731

171. Zoglmeier C, Bauer H, Nörenberg D, Wedekind G, Bittner P, Sandholzer N, et al. CPG blocks immunosuppression by myeloid-derived suppressor cells in tumour-bearing mice. Clin Cancer Res (2011) 17:1765-75. doi:10.1158/10780432.CCR-10-2672

172. Cubillos-Ruiz JR, Baird JR, Tesone AJ, Rutkowski MR, Scarlett UK, CamposecoJacobs AL, et al. Reprogramming tumour-associated dendritic cells in vivo using miRNA mimetics triggers protective immunity against ovarian cancer. Cancer Res (2012) 72:1683-93. doi:10.1158/0008-5472.CAN-11-3160

173. Chmielewski M, Kopecky C, Hombach AA, Abken H. IL-12 release by engineered $\mathrm{T}$ cells expressing chimeric antigen receptors can effectively muster an antigen-independent macrophage response on tumour cells that have shut down tumour antigen expression. Cancer Res (2011) 71:5697-706. doi:10.1158/0008-5472.CAN-11-0103

174. Kerkar SP, Goldszmid RS, Muranski P, Chinnasamy D, Yu Z, Reger RN, et al. IL-12 triggers a programmatic change in dysfunctional myeloid-derived cells within mouse tumours. J Clin Invest (2011) 121:4746-57. doi:10.1172/ JCI58814

175. Ugel S, Delpozzo F, Desantis G, Papalini F, Simonato F, Sonda N, et al. Therapeutic targeting of myeloid-derived suppressor cells. Curr Opin Pharmacol (2009) 9:470-81. doi:10.1016/j.coph.2009.06.014

176. Iclozan C, Antonia S, Chiappori A, Chen D, Gabrilovich D. Therapeutic regulation of myeloid-derived suppressor cells and immune response to cancer vaccine in patients with extensive stage small cell lung cancer. Cancer Immunol Immunother (2013) 62:909-18. doi:10.1007/s00262-013-1396-8

177. Steinbrink K, Wölfl M, Jonuleit H, Knop J, Enk AH. Induction of tolerance by IL-10-treated dendritic cells. J Immunol (1997) 159:4772-80.

178. Torres-Aguilar H, Aguilar-Ruiz SR, González-Pérez G, Munguía R, Bajaña $\mathrm{S}$, Meraz-Ríos MA, et al. Tolerogenic dendritic cells generated with different immunosuppressive cytokines induce antigen-specific anergy and regulatory properties in memory cd4+ T cells. J Immunol (2010) 184:1765-75. doi:10.4049/jimmunol.0902133

179. Penna G, Adorini L. 1 Alpha,25-dihydroxyvitamin D3 inhibits differentiation, maturation, activation, and survival of dendritic cells leading to impaired alloreactive T cell activation. J Immunol (2000) 164:2405-11.

180. Xia C, Peng R, Beato F, Clare-Salzler MJ. Dexamethasone induces IL-10producing monocyte-derived dendritic cells with durable immaturity. Scand J Immunol (2005) 62:45-54. doi:10.1111/j.1365-3083.2005.01640.x

181. Matsumoto T, Hasegawa H, Onishi S, Ishizaki J, Suemori K, Yasukawa M. Protein kinase $\mathrm{C}$ inhibitor generates stable human tolerogenic dendritic cells. J Immunol (2013) 191:2247-57. doi:10.4049/jimmunol.1203053

182. Taner T, Hackstein H, Wang Z, Morelli AE, Thomson AW. Rapamycin-treated, alloantigen-pulsed host dendritic cells induce AG-specific T cell regulation and prolong graft survival. Am J Transplant (2005) 5:228-36. doi:10.1046/j.16006143.2004.00673.x

183. Manicassamy S, Pulendran B. Dendritic cell control of tolerogenic responses. Immunol Rev (2011) 241:206-27. doi:10.1111/j.1600-065X.2011.01015.x

184. Nikolic T, Roep BO. Regulatory multitasking of tolerogenic dendritic cells lessons taken from vitamin d3-treated tolerogenic dendritic cells. Front Immunol (2013) 4:113. doi:10.3389/fimmu.2013.00113

185. Stoop JN, Harry RA, von Delwig A, Isaacs JD, Robinson JH, Hilkens CMU. Therapeutic effect of tolerogenic dendritic cells in established collagen-induced arthritis is associated with a reduction in TH17 responses. Arthritis Rheum (2010) 62:3656-65. doi:10.1002/art.27756

186. Zhang A, Fu J, Ning B, Li D, Sun N, Wei W, et al. Tolerogenic dendritic cells generated with IL-10/TGF $\beta 1$ relieve immune thrombocytopenia in mice. Thromb Res (2013) 132:63-8. doi:10.1016/j.thromres.2013.04.001

187. Farias AS, Spagnol GS, Bordeaux-Rego P, Oliveira COF, Fontana AGM, de Paula RFO, et al. Vitamin D3 induces IDO (+) tolerogenic DCS and enhances Treg, reducing the severity of EAE. CNS Neurosci Ther (2013) 19:269-77. doi:10.1111/cns.12071

188. Turnquist HR, Raimondi G, Zahorchak AF, Fischer RT, Wang Z, Thomson AW. Rapamycin-conditioned dendritic cells are poor stimulators of allogeneic CD4+ T cells, but enrich for antigen-specific FOXP3 $+\mathrm{T}$ regulatory cells and promote organ transplant tolerance. J Immunol (2007) 178:7018-31.

189. Raïch-Regué D, Grau-López L, Naranjo-Gómez M, Ramo-Tello C, PujolBorrell R, Martínez-Cáceres E, et al. Stable antigen-specific T-cell hyporesponsiveness induced by tolerogenic dendritic cells from multiple sclerosis patients. Eur J Immunol (2012) 42:771-82. doi:10.1002/eji.201141835

190. Hilkens CMU, Isaacs JD. Tolerogenic dendritic cell therapy for rheumatoid arthritis: where are we now? Clin Exp Immunol (2013) 172:148-57. doi:10.1111/cei.12038

191. Machen J, Harnaha J, Lakomy R, Styche A, Trucco M, Giannoukakis N. Antisense oligonucleotides down-regulating costimulation confer diabetespreventive properties to nonobese diabetic mouse dendritic cells. J Immunol (2004) 173:4331-41.

192. Giannoukakis N, Phillips B, Finegold D, Harnaha J, Trucco M. Phase I (safety) study of autologous tolerogenic dendritic cells in type 1 diabetic patients. Diabetes Care (2011) 34:2026-32. doi:10.2337/dc11-0472 
193. Giannoukakis N, Bonham CA, Qian S, Chen Z, Peng L, Harnaha J, et al. Prolongation of cardiac allograft survival using dendritic cells treated with NF-KB decoy oligodeoxyribonucleotides. Mol Ther (2000) 1:430-7. doi:10.1006/mthe. 2000.0060

194. Wada Y, Cardinale I, Khatcherian A, Chu J, Kantor AB, Gottlieb AB, et al. Apilimod inhibits the production of IL-12 and IL-23 and reduces dendritic cell infiltration in psoriasis. PLoS One (2012) 7:e35069. doi:10.1371/journal.pone. 0035069

195. Krausz S, Boumans MJH, Gerlag DM, Lufkin J, van Kuijk AWR, Bakker A, et al. Brief report: a phase IIA, randomized, double-blind, placebo-controlled trial of apilimod mesylate, an interleukin-12/interleukin-23 inhibitor, in patients with rheumatoid arthritis. Arthritis Rheum (2012) 64:1750-5. doi:10.1002/art.34339

196. Burakoff R, Barish CF, Riff D, Pruitt R, Chey WY, Farraye FA, et al. A phase $1 / 2$ a trial of STA 5326, an oral interleukin-12/23 inhibitor, in patients with active moderate to severe Crohn's disease. Inflamm Bowel Dis (2006) 12:558-65. doi:10.1097/01.ibd.0000225337.14356.31

197. Sands BE, Jacobson EW, Sylwestrowicz T, Younes Z, Dryden G, Fedorak R, et al. Randomized, double-blind, placebo-controlled trial of the oral interleukin$12 / 23$ inhibitor apilimod mesylate for treatment of active Crohn's disease. Inflamm Bowel Dis (2010) 16:1209-18. doi:10.1002/ibd.21159

198. Lan Z, Ge W, Arp J, Jiang J, Liu W, Gordon D, et al. Induction of kidney allograft tolerance by soluble CD83 associated with prevalence of tolerogenic dendritic cells and indoleamine 2,3-dioxygenase. Transplantation (2010) 90:1286-93. doi:10.1097/TP.0b013e3182007bbf

199. Zinser E, Lechmann M, Golka A, Lutz MB, Steinkasserer A. Prevention and treatment of experimental autoimmune encephalomyelitis by soluble CD83. J Exp Med (2004) 200:345-51. doi:10.1084/jem.20030973

200. Mukhopadhaya A, Hanafusa T, Jarchum I, Chen Y, Iwai Y, Serreze DV, et al. Selective delivery of beta cell antigen to dendritic cells in vivo leads to deletion and tolerance of autoreactive CD8+ T cells in nod mice. Proc Natl Acad Sci U $S$ A (2008) 105:6374-9. doi:10.1073/pnas.0802644105

201. Ring S, Maas M, Nettelbeck DM, Enk AH, Mahnke K. Targeting of autoantigens to DEC205+ dendritic cells in vivo suppresses experimental allergic encephalomyelitis in mice. J Immunol (2013) 191:2938-47. doi:10.4049/ jimmunol.1202592
202. Meyer-Wentrup F, Benitez-Ribas D, Tacken PJ, Punt CJA, Figdor CG, de Vries IJM, et al. Targeting DCIR on human plasmacytoid dendritic cells results in antigen presentation and inhibits IFN-alpha production. Blood (2008) 111:4245-53. doi:10.1182/blood-2007-03-081398

203. Meyer-Wentrup F, Cambi A, Joosten B, Looman MW, de Vries IJM, Figdor CG, et al. DCIR is endocytosed into human dendritic cells and inhibits TLR8mediated cytokine production. J Leukoc Biol (2009) 85:518-25. doi:10.1189/ jlb.0608352

204. Loschko J, Heink S, Hackl D, Dudziak D, Reindl W, Korn T, et al. Antigen targeting to plasmacytoid dendritic cells via SIGLEC-H inhibits TH cell-dependent autoimmunity. J Immunol (2011) 187:6346-56. doi:10.4049/ jimmunol.1102307

205. Ricupito A, Grioni M, Calcinotto A, Hess Michelini R, Longhi R, Mondino A et al. Booster vaccinations against cancer are critical in prophylactic but detrimental in therapeutic settings. Cancer Res (2013) 73:3545-54. doi:10.1158/ 0008-5472.CAN-12-2449

Conflict of Interest Statement: The authors declare that the research was conducted in the absence of any commercial or financial relationships that could be construed as a potential conflict of interest.

Received: 23 September 2013; paper pending published: 08 October 2013; accepted: 17 November 2013; published online: 02 December 2013.

Citation: Seliger B and Massa C (2013) The dark side of dendritic cells: development and exploitation of tolerogenic activity that favor tumor outgrowth and immune escape. Front. Immunol. 4:419. doi: 10.3389/fimmu.2013.00419

This article was submitted to Tumor Immunity, a section of the journal Frontiers in Immunology.

Copyright (c) 2013 Seliger and Massa. This is an open-access article distributed under the terms of the Creative Commons Attribution License (CC BY). The use, distribution or reproduction in other forums is permitted, provided the original author (s) or licensor are credited and that the original publication in this journal is cited, in accordance with accepted academic practice. No use, distribution or reproduction is permitted which does not comply with these terms. 